\begin{tabular}{|l|l|l||}
\hline \multicolumn{2}{|c|}{ PublisherInfo } \\
\hline \hline PublisherName & $:$ & BioMed Central \\
\hline \hline PublisherLocation & $:$ & London \\
\hline \hline PublisherImprintName & $:$ & BioMed Central \\
\hline \hline
\end{tabular}

\title{
Brca1 and homologous recombination
}

\begin{tabular}{|l|l|l||}
\hline \multicolumn{2}{|c|}{ ArticleInfo } \\
\hline \hline ArticleID & $:$ & 3644 \\
\hline \hline ArticleDOI & $:$ & $10.1186 /$ bcr-1999-66622 \\
\hline \hline ArticleCitationID & $:$ & 66622 \\
\hline \hline ArticleSequenceNumber & $:$ & 64 \\
\hline \hline ArticleCategory & $:$ & Paper Report \\
\hline ArticleFirstPage & $:$ & 1 \\
\hline \hline ArticleLastPage & $:$ & 4 \\
\hline \hline & & RegistrationDate : 1999-11-2 \\
\hline ArticleHistory & $:$ & OnlineDate \\
\hline \hline ArticleCopyright & $:$ & Current Science Ltd1999-11-2 \\
\hline \hline ArticleGrants & $:$ & \\
\hline \hline ArticleContext & $:$ & 1305811 \\
\hline \hline
\end{tabular}




\section{Keywords}

Double strand break, gene targeting, homologous recombination, mouse embryonic stem cells, nonhomologous end joining

\section{Introduction}

Mouse and human cells mutant for $B R C A 1$ or $B R C A 2$ are sensitive to DNA-damaging agents, implicating these genes in the response to DNA damage. Mammalian cells have two major pathways for the repair of DNA double-strand breaks (DSBs), homologous recombination and non-homologous end joining (NHEJ). The BRCA1 and BRCA2 proteins colocalise with RAD51, the mammalian equivalent of the yeast Rad51 protein, which is involved in the repair of DNA DSBs by homologous recombination. This has led to the view that BRCA1 and BRCA2 might also be involved in the repair of DNA DSBs by homologous recombination.

\section{Aims}

To determine whether mutation of the Brcal gene impairs the repair of DNA DSBs by either homologous recombination or NHEJ.

\section{Comments}

Although a role for Brcal in the repair of DNA DSBs by homologous recombination has been suggested by previous studies, this important paper is the first to directly demonstrate such a role.

\section{Methods}

Gene targeting. Analysis of DNA repair at a restriction endonuclease site following endonuclease digestion. 


\section{Results}

Gene targeting efficiencies in Brca1-/- embryonic stem (ES) cells were compared with those of Brca1+/- ES cells for two targeting vectors. A pim1-Q targeting vector with a promoterless hygromycin resistance gene was 23-fold less efficient in Brca1-/- ES cells. An Rb targeting vector with a PGK promoter driven hygromycin resistance gene was 53 -fold less efficient in Brca1-/- ES cells. This 53-fold difference was due to a 13-fold decrease in gene targeting and a four fold increase in random integration.

DNA repair substrates containing the rare cutting endonuclease, I-SceI were integrated at the pim 1 and $R b$ loci, in Brca1-/- and Brca1+/- ES cells. DSBs were introduced at the I-SceI site by electroporating cells with an I-SceI expression plasmid, and the resulting repair products were analysed using two assays. Compared to Brca1+/- cells, the Brca1-/- cells have a five to six fold lower level of homologous repair of DNA DSBs. No decrease in NHEJ was observed in Brca1-/- cells, rather it was increased by 1.5 to 1.6 -fold.

\section{Discussion}

The slight elevation in NHEJ in Brca1-/- cells, as measured by increased random integration of transfected DNA, may reflect an elevated level of spontaneous DSBs into which transfected DNA can insert. This could be due to the homologous repair defect in the Brcal-/- cells.

The Brcal mutation in this study disrupts the terminal part of exon 10 and the beginning of exon 11. This does not result in a complete null allele, since an exon 10-12 splice variant is expressed. This variant does not contain exon 11, which encodes the RAD51 interacting domain as mapped in the human protein.

Impaired repair of DNA DSBs by homologous recombination would be predicted to result in genetic instability. Recent studies showing chromosomal abnormalities in Brcal-deficient mouse and human cells support a role for Brcal in the maintenance of genetic stability.

\section{References}


1. Moynahan ME, Chiu JW, Koller BH, Jasin M: Brcal controls homology-directed DNA repair. Mol Cell. 1999, 4: 511-518. 